\title{
AMERICAN NEOSCONA AND CORRECTIONS TO PREVIOUS REVISIONS OF NEOTROPICAL ORB-WEAVERS \\ (ARANEAE: ARANEIDAE)
}

\author{
By Herbert W. LEVI \\ Museum of Comparative Zoology \\ Harvard University \\ Cambridge MA
}

\section{INTRODUCTION}

One of the first revisions of American araneids was that of Neoscona (Berman and Levi, 1971). At the time I was undecided whether to revise the Nearctic and Neotropical species together or separately. Soon it became evident that, although undesirable, a geographic division had to be made. Most of the Nearctic species were well represented in collections but there were only a few specimens of the Neotropical species. Collections of the American Museum of Natural History and the Museum of Comparative Zoology were the main ones used. At present large collections of Neotropical spiders are available on loan which we did not have in 1970. Grasshoff's revision (1986) of African Neoscona found that Africa and America share some species but that Africa has species belonging to the subgenus Afraranea which are not found in the Americas. But since most of the Neoscona species are found in the area of eastern Asia and western Pacific, our knowledge of Neoscona species is still limited. Neoscona species are easily transported and are part of the unfortunate homogenization of the world fauna. I suspect that the new Neoscona marcanoi from Hispaniola, and $N$. oaxacensis (Keyserling) may be the only native species found in the American tropics. This paper is an addition to the previous revision (Berman and Levi, 1971).

The records of specimens included in previous maps (Berman and Levi, 1971) have not been individually listed; most came either from the AMNH or MCZ collections. In the present paper, the previous localities are plotted again, together with the new records, which are listed together with their collections.

Manuscript received 15 May 1992 
This paper also includes corrections and additions to previous monographs. After completion of a generic revision, I invariably get specimens sent to me that cannot be determined with my keys and illustrations. Most turn out to be new species. Also I find omissions, errors and misprints. However, the omission of a previously described species, and perhaps one whose genitalia have not been illustrated before, may lead to a redescription as a new species and a possible later synonymy. Also some species turn out to be misplaced, a discovery made only after a specimen of the other sex becomes known. This also has to be corrected.

Credits. I would like to thank the curators of the following museums and the individuals who loaned specimens.

AD, A. Dean, Texas A and M University, College Station, Texas

AMNH, American Museum of Natural History, New York; N.

Platnick, L. Sorkin

BMNH, The Natural History Museum, London, England; P. Hillyard, F. Wanless

CAS, California Academy of Sciences, San Francisco; W. J. Pulawski, D. Ubick

CD, C. Deeleman, Ossendrecht, Netherlands

CV, C. Valderrama A., Bogotá, Colombia

FSCA, Florida State Collection of Arthropods, Gainesville, Florida; G. B. Edwards

IBNP, Inventario Biologico Nacional, Paraguay; J. A. Kochalka

INPA, Instituto Nacional de Pesquisas da Amazonia, Manaus, Est. Amazonas Brazil; J. A. Raphael

JAK, J. A. Kochalka, Ciudad Universitaria, Paraguay

JMM, J. M. Maes, León, Nicaragua

MACN, Museo Argentino de Ciencias Naturales, Buenos Aires, Argentina; E. A. Maury

MECN, Museo Ecuatoriano de Ciencias Naturales, Quito, Ecuador; L. Avilés

MCN, Museu de Ciências Naturais, Porto Alegre, Rio Grande do Sul, Brazil; E. H. Buckup

MCZ, Museum of Comparative Zoology, Cambridge, Massachusetts

MEG, M. E. Galiano; Buenos Aires, Argentina

MLP, Museo de Universidad Nacional, La Plata, Argentina; R. F. Arrozpide 
MNHNC, Museo Nacional de Historia Natural, Habana, Cuba; G. Alayón

MNSD, Museo Nacional de Historia Natural, Santo Domingo, República Dominicana

MNRJ, Museu Nacional, Rio de Janeiro, Brazil; A. Timotheo da Costa

MUCC, Museo de Biología, Universidad Central, Caracas, Venezuela, J. Racenis

MUSM, Museo de Historia Natural, Universidad Nacional Mayor de San Marcos, Lima, Peru; D. Silva D.

MZSP, Museu de Zoologia da Universidade de São Paulo, São Paulo, Brazil; P. Vanzolini, L. Neme, J. L. M. Leme

PAN, Polska Akademia Nauk, Warszawa, Poland; A. Riedel, W. Starega, J. Proszynski, A. Slojewska, E. Kierych

SMF, Forschungsinstitut Senckenberg, Frankfurt am Main, Germany; M. Grasshoff

USNM, National Museum of Natural History, Smithsonian Institution, Washington, D.C.; J. Coddington

ZMK, Zoologisk Museum, København, Denmark; H. Enghoff

I would also like to thank J. Martinez for a California record and E. Buckup for determining Neoscona in the MCN and sending me the records. E. Buckup, A. Lise, and L. Leibensperger made me aware of some errors, misprints and omissions in previous monographs. A. Dean, C. Deeleman, H. Höfer, and A. A. Lise contributed specimens. E. Buckup, M. Grasshoff, and L. Leibensperger read the paper and made suggestions for improvement.

\section{Neoscona Simon}

Neoscona Simon, 1864: 261. Type species designated by F. P.Cambridge, 1904: Epeira arabesca F. P.-Cambridge.

Diagnosis. Male palpal patella with two macrosetae and with oval median apophysis of palpus bearing a proximal "upper" recurved tooth (similar in all species, $\mathrm{M}$ in Fig. 6). Neoscona differs from other araneid genera with two palpal macrosetae (Araneus, Aculepeira, Larinia, Metepeira) by the structure of the palpus (Figs. 6-8, 16; 1971, figs. 4-6): a large area of the bulb is a folded basal hematodocha $(\mathrm{H})$, and only a small area has sclerites. 
Unlike in other genera, the sclerites are partly hidden by a wide cymbium (Y, Fig. 6) which touches a small median apophysis (M); the radix is fused to the stipes or has a joint; the stipes is distally three-partite with a conical embolus (E), an embolus lamella (L), and a terminal apophysis (A), the last two only lightly sclerotized. There is almost no distal hematodocha between embolus and terminal apophysis.

Female Neoscona differ from other genera by a curved, spatulashaped epigynum whose sclerites appear fused (Figs. 1-3). The epigynum of $N$. nautica (Fig. 10) can be confused with that of Ocrepeira species.

Unrecognizable. Neoscona nigrovariata Mello-Leitão, 1941:258.

The species north of the Isthmus of Tehuantepec are: Neoscona arabesca, $N$. domiciliorum, $N$. crucifera $(=N$. hentzii), $N$. nautica, $N$. oaxacensis, $N$. orizabensis, $N$. pratensis, $N$. utahana.

Misplaced by Berman and Levi (1971) was $N$. redempta (Gertsch and Mulaik) which is Ocrepeira redempta (Levi, in press).

The Central American species are $N$. arabesca, $N$. nautica, and N. oaxacensis.

The West Indian species are N. moreli, N. nautica, and N. marcanoi n. sp., with only $N$. marcanoi native, the other two introduced.

The South American species are $N$. oaxacensis and the introduced $N$. moreli and $N$. nautica. The distinguishing characters of these species are the dorsal pattern of the abdomen, the shape of the epigynum and the conductor (C in Figs. 6-8, 16), the terminal apophysis (A), and the embolus lamella (L) of the palpus.

Key to the species of South American Neoscona

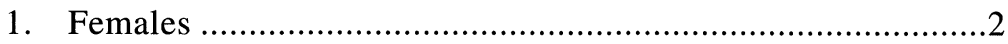

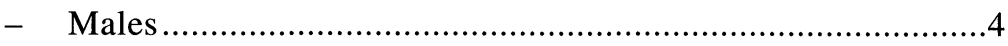

2(1)Abdomen rounded, Araneus-like; only slightly longer than wide (Fig. 11). Epigynum about as wide as long (Fig. 10) nautica

- Abdomen oval and elongate (Figs. 15, 19, 23); epigynum distinctly longer than wide (Figs. 14, 18, 22). 


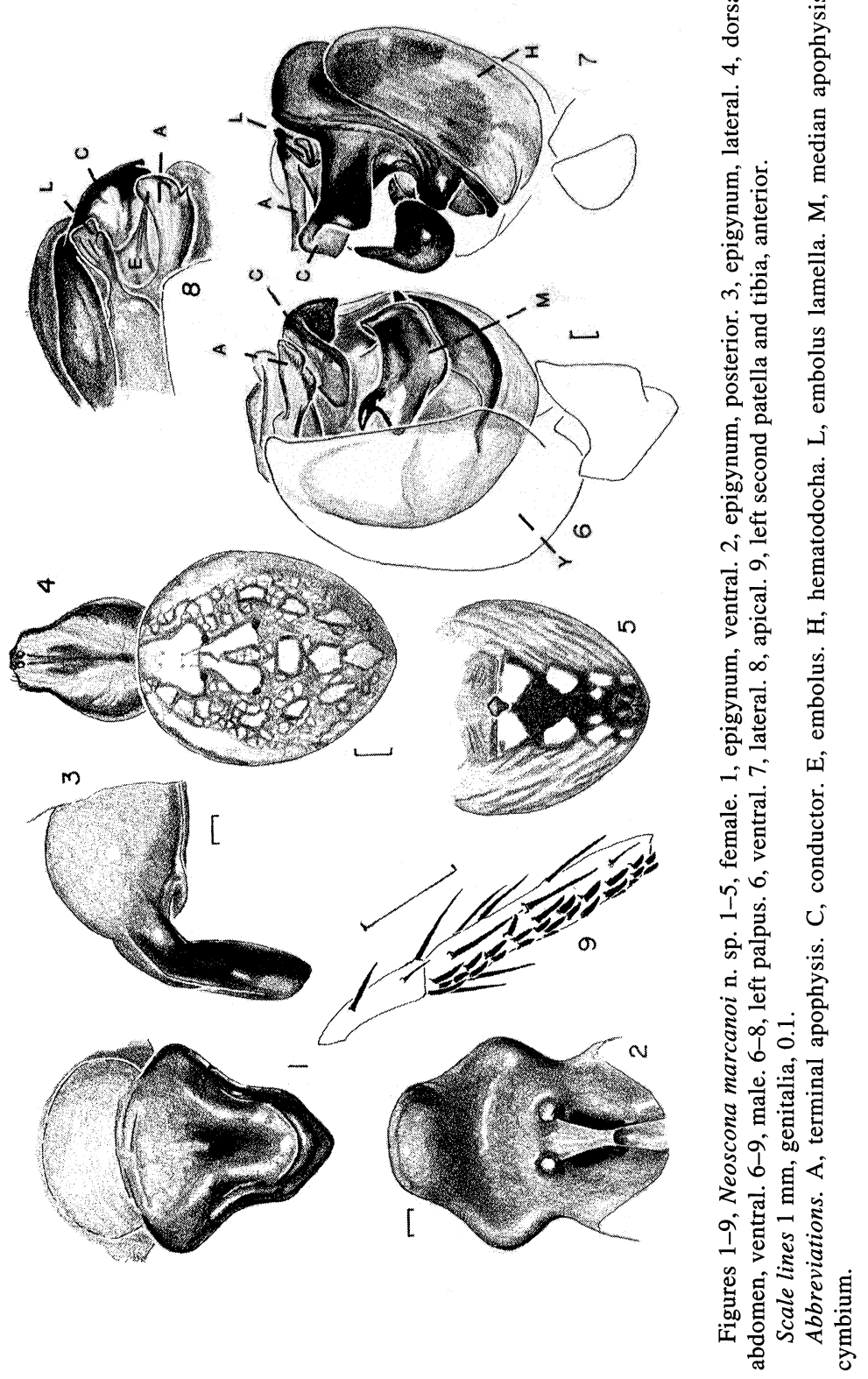

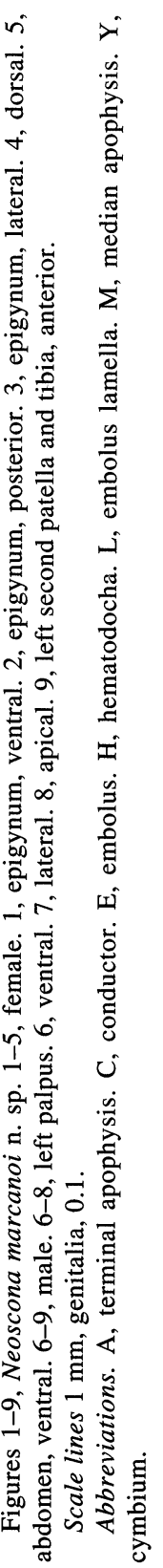


3(2)Abdomen with dorsal median band having wavy border, wider anteriorly than posteriorly (Fig. 23); epigynum in posterior view 2.5 times as long as wide (Fig. 22; 1971, figs. 78-80)

oaxacensis

- Abdomen with dorsal median band having a straight border (Fig. 19); epigynum length in posterior view less than two times its width (Fig. 18; 1971, figs. 91-95)......................moreli

4(1)Fourth coxa with a soft tubercle (1971, fig. 9) .......................5

- Fourth coxa without tubercle........................................nautica

5(4)Abdomen with median light band with straight border (Fig. 19, 1971, fig. 100); palpus in lateral view with conductor (C) almost straight, embolus lamella (L) pressed flat against tegulum (T) and only side of terminal apophysis (A) visible (Fig. 20). moreli

- Abdomen with median light band with wavy border (Fig. 23, 1971, figs. 88-90); palpus in lateral view with conductor Sshaped and having the proximal end with a curved shelf; only side of lamella (L) and top of terminal apophysis (A) visible in lateral view of palpus (Fig. 24) oaxacensis

\section{Neoscona marcanoi new species}

Figures 1-9; Map 1

Holotype. Female holotype and eight female and one male paratypes from Terreno Salado between Neiba and Duvergé, Dominican Republic, Hispaniola, 25 Oct. 1980 (E. Marcano F.), in MNSD, $2 Q$ paratypes in MCZ. The species is named after the collector.

Description. Female holotype: Carapace light yellowish, darker in median band and on sides. Sternum orange, underlain by median white pigment band. Coxae orange; legs yellow. Dorsum of abdomen with median band of large white patches, smaller one on the sides (Fig. 4); venter black with four white patches and a pair of white spots on each side of spinnerets (Fig. 5). Posterior median eyes 0.9 diameter of anterior medians, laterals 0.8 diameter. Anterior median eyes slightly less than their diameter apart, two diameters from laterals. Posterior median eyes 0.6 diameter apart, 3 diameters from laterals. Height of clypeus 0.6 diameters of anterior median eye. Abdomen an elongate oval (Fig. 4). Total length 10.3 


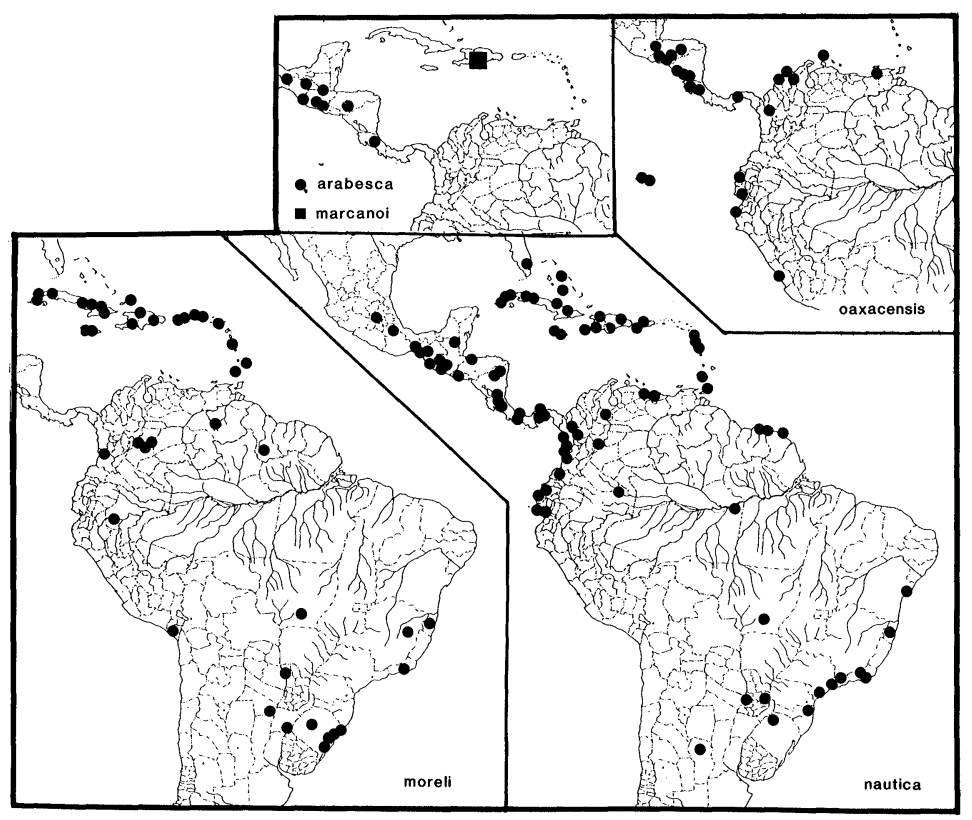

Map 1, Distribution of Neotropical Neoscona species.

mm. Carapace $5.1 \mathrm{~mm}$ long, 4.0 wide, behind lateral eyes 1.8 wide. First femur $5.7 \mathrm{~mm}$, patella and tibia 6.9, metatarsus 5.7 , tarsus 1.4. Second patella and tibia $5.9 \mathrm{~mm}$, third 3.5 , fourth 5.8 .

Male paratype: Color as in female, but venter of abdomen gray with white spots touching. Posterior median eyes 0.7 diameter of anterior medians, laterals 0.7 diameter. Anterior median eyes their diameter apart, 1.3 diameters from laterals. Posterior median eyes their diameter apart, 2.3 diameters from laterals. Height of clypeus 0.6 diameter of anterior median eye. Endite with tooth, palpal femur with tooth. First coxa with hook, fourth with a tubercle on posterior face. Second tibia thicker than first, swollen, with prolateral macrosetae (Fig. 9). Abdomen oval. Total length $7.0 \mathrm{~mm}$. Carapace $3.6 \mathrm{~mm}$ long, 2.7 wide, behind lateral eyes 1.1 wide. First femur $4.8 \mathrm{~mm}$, patella and tibia 6.3 , metatarsus 5.7 , tarsus 1.3. Second patella and tibia $4.3 \mathrm{~mm}$, third 2.6 , fourth 4.6 . 
Note: This is probably a native species, not introduced. Males and females were collected together. Illustrations were made from holotype and paratype.

Diagnosis. The female differs from that of $N$. moreli by a shorter abdomen, marked dorsally with light spots (Fig. 4), and by a shorter, wider epigynum (Fig. 1) which is wider at the lateral lobes than at its base (Fig. 2). The male differs by having the conductor with a dark, sclerotized lobe (Fig. 7) and by the shape of the terminal apophysis (A) and embolus lamella (L) (Figs. 7, 8). The second tibia has a dense field of setae (Fig. 9).

Paratype. DOMINICAN REPUBLIC: $1 \mathrm{~km}$ S Las Matas de Fartan, 25 Aug. 1970, o (B. Patterson, MCZ).

\section{Neoscona nautica (L. Koch)}

Figures. 10-13; Map 1

Epeira tristis Taczanowski, 1873: 131. Female holotype from Iles de Salut, French Guiana in PAN, examined. Name preoccupied by Epeira tristis Blackwall, 1862. Synonymized by Berman and Levi, 1971.

Epeira nautica L. Koch, 1875: 17. pl. 2, fig. 2., ○. Female holotype from Suakin [Sudan], in BMNH, examined.

Epeira volucripes Keyserling, 1885: 528, pl. 13, fig. 27, ९. Female syntypes from Panama and Haiti in MCZ, examined.

Neoscona volucripes: - F. P.-Cambridge, 1904: 473, pl. 44, fig. 18 , o.

Aranea tristimonae Petrunkevitch, 1911: 320. New name for Epeira tristis Taczanowski, preoccupied. Synonymized by Berman and Levi, 1971.

Araneus marcuzzii Caporiacco, 1955: 355, fig. 35, o. Female holotype from Carúpano, Sucre, Venezuela, in MUCC, examined. Synonymized by Berman and Levi, 1971.

Neoscona nautica: - Berman and Levi, 1971: 498, figs 111-120, ९, ơ. Grasshoff, 1986: 46, figs. 60-63, ९, ơ, map 6.

Diagnosis. The female abdomen is almost as wide as long (Fig. 11) and can be confused with that of Araneus species; unlike in other American Neoscona the terminal apophysis of the palpus is very small (Fig. 12); the second tibia (Fig. 13) lacks the dense field of short setae present in $N$. moreli. 

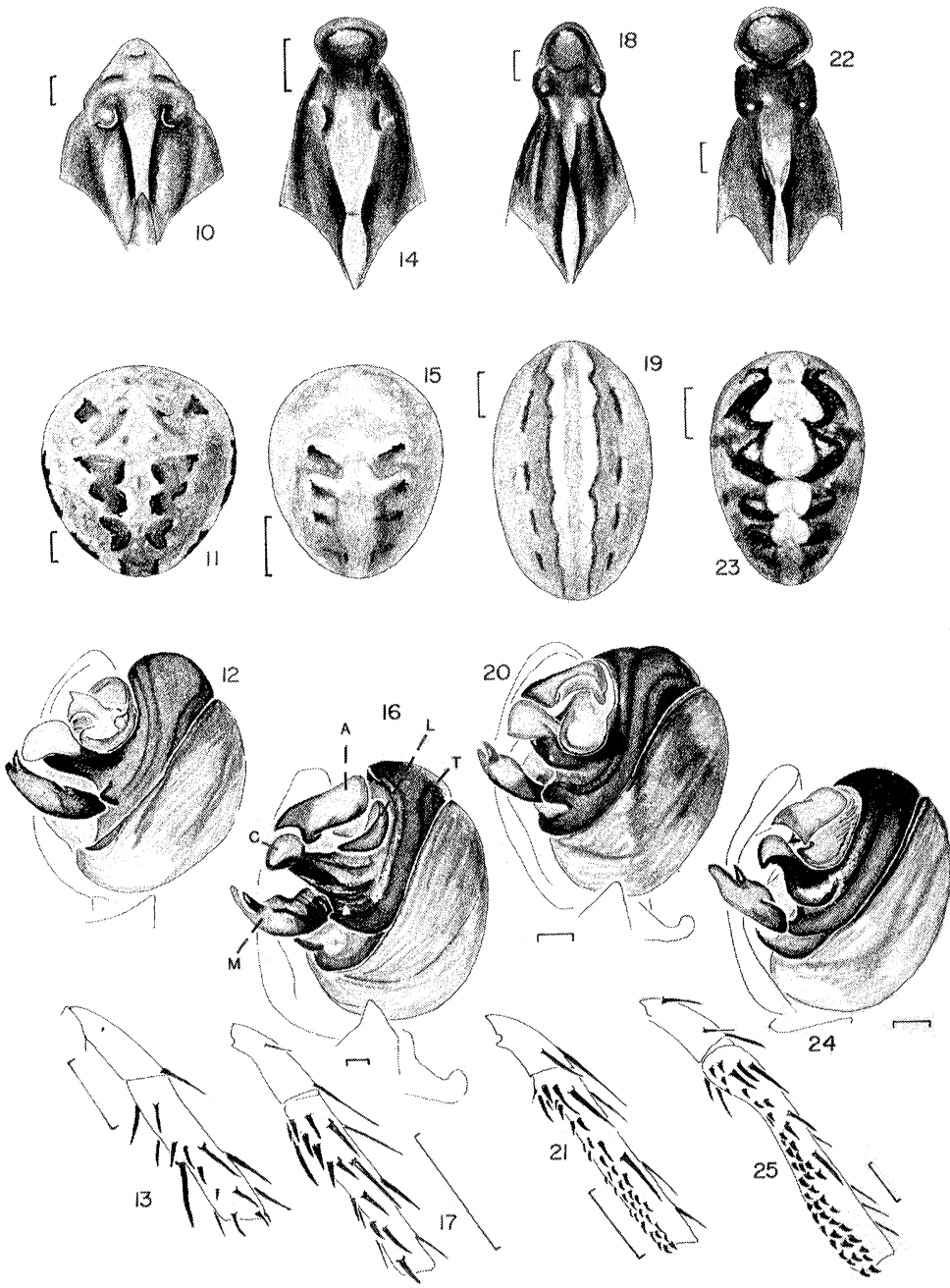

Figures 10-13, Neoscona nautica. 10, epigynum, posterior. 11, abdomen of female. 12, male left palpus, lateral. 13, male left second patella and tibia, anterior. Figures 14-17, $N$. arabesca. 14, epigynum, posterior. 15, abdomen of female. 16, male palpus, lateral. 17, male second patella and tibia, anterior. Figures 18-21, $N$. moreli. 18, epigynum, posterior. 19, abdomen of female. 20, male palpus, lateral. 21 , male second patella and tibia, anterior. Figures 22-25, N. oaxacensis. 22, epigynum, posterior. 23 , abdomen of female. 24 , male palpus, lateral. 25 , male second patella and tibia, anterior.

Scale lines $1 \mathrm{~mm}$; genitalia 0.1 .

Abbreviations. A, terminal apophysis. C, median apophysis. L, embolus lamella. $\mathrm{M}$, median apophysis. T, tegulum. 
Note. The illustrations were made from a female from Depto. Antioquia, the male from Depto. Valle, Colombia, the male tibia and patella from Puerto Rico.

Distribution. Cosmotropical: widespread in tropical areas of Africa; in America from Virginia, Texas, and the West Indies to Argentina. It is probably introduced to America.

New records. CUBA Holquin: Farallones de Moa (MNHNC). Habana: Ojo de Agua de Nico, S. A. Baños (MNHNC). HAITI Port au Prince (MCZ). MONA ISLAND (MCZ). GUATEMALA Suchitepequez: San Julian (AMNH). Peten: Tikal ruins (MCZ). Chimaltenango: Yepokapa (AMNH, USNM). NICARAGUA Bonanza (AMNH); El Castillo (JMM, MCZ). COSTA RICA Heredia: La Selva (AMNH). San José: San José (CAS). PANAMA Boca del Toro: Coroente Grande, Changuinola (MCZ); Río Chanquinola nr. Quebrada El Guabo (AMNH). Chiriquí: David (AMNH), Balboa (AMNH). VENEZUELA Carabobo: San Esteban (AMNH). SURINAM Morowijne: Langaman (AMNH). COLOMBIA César: Valledupar (JAK). Cundinamarca: Tibirita, in house (MCZ). Guajira: Maicao (AMNH). Antioquia: Mutatá Cancheras (MCZ); Medellín (MCZ). Chocó; Mutis, Bahia Solano (CAS); between Cucurrupí and Noanama, Río San Juán (AMNH); Caño nr. Cucurrupí, Río San Juán (AMNH); 20 km N Palestina, Río San Juán (AMNH). Valle: Centr. Hld. Anchicayá (MCZ). Amazonas: Araracuara, 270 m (CV). Nariño: Reserva Nat. La Planada, Ricaurte, $1350 \mathrm{~m}$ (CV). ECUADOR Guayas: Guayaquil (CAS, MACN); Colonche (CAS). Manabi: Crucita, $0^{\circ} 52 ' \mathrm{~S}, 80^{\circ} 32^{\prime} \mathrm{W}$ (MCZ); El Carmen (MECN). BRAZIL Amazonas: Maués (INPA). Bahia: Itamaraju (MNRJ). Rio de Janeiro: Rio de Janeiro (ZMK); Petrópolis (AMNH). Mato Grosso: Chapada dos Guimarães (AMNH). Santa Catarina: Corupá (AMNH). São Paulo: Juquiá (MZSP); Piquete (MZSP); Santos (MZSP); Raiz de Serra (MZSP). Rio Grande do Sul: Santa Rosa (MCN). PARAGUAY Central: Asuncion (MNRJ). Alto Paraná: km 12 de Stroessner, Centro Forestal de Alto Paraná (IBNP). ARGENTINA Córdoba: General Paz (MLP).

Neoscona arabesca (Walckenaer)

Figures 14-17; Map 1

Epeira arabesca Walckenaer, 1841: 74 . The name was given to the specimen illustrated by L. A. G. Bosc, unpublished. Araignées 
de Caroline, p. 13, pl. 5, fig. 2, in the library of The Natural History Museum, London.

Neoscona arabesca: - Berman and Levi, 1971: 474, Figs. 14 to 35, ○, ơ.

Diagnosis. This is the smallest and commonest North American species. The female has an egg-shaped abdomen, with characteristic pairs of diagonal marks (Fig. 15 and 1971, figs. 34, 35). The male has the edge of the embolus lamella (L) and terminal apophysis (A) almost parallel and the conductor (C) relatively straight (Fig. 16). The male left second tibia (Fig. 17) lacks the field of short setae present in some other Neoscona species.

Note. The illustrations of the female were made from an individual from Costa Rica, that of the male palpus from a specimen from Talapa, Mexico, the patella and tibia from a male from Cuba.

Natural History. Specimens came from a sorghum field in Honduras; others were found in meadows and open areas.

Distribution. Common from southern Canada and the United States south to Costa Rica, Bahamas, Cuba, Hispaniola, and Jamaica.

New records. GUATEMALA Antigua: Finca Salinas, 29 June 1980, 3o (J. Schuster, FSCA). HONDURAS 37 km E Tegucigalpa, sorghum fields, ᄋ, 2 Dec. 1982 (R. W. Jones, MCZ). COSTA RICA San José: San José, o, ơ (E. Schmidt, AMNH).

\section{Neoscona crucifera (Lucas)}

Epeira crucifera Lucas, 1839: 42, pl. 6, fig. 3. Specimens from the Canary Islands.

Epeira hentzii Keyserling, 1864: 97, pl. 5, fig. 10, 11, ᄋ. Female lectotype designated by Berman and Levi, 1971 in BMNH. Synonymized by Grasshoff, 1986.

Neoscona hentzii: - Berman and Levi, 1971: 478, figs. 51-58.

Neoscona crucifera: - Grasshoff, 1986: 62, figs. 79-84, o, ơ, map

9; Martinez (in press).

Diagnosis. The abdomen is almost as wide as long.

Natural history. Martinez reports (personal communication Feb. 1992) that the species is getting more abundant in southern California and builds webs higher up than the webs of $N$. oaxacensis.

Distribution. New England to California and central Mexico; Canary Islands Madeira and Porto Santo, Africa. Presumably this 
species has been carried from America to Africa. Heretofore unknown from California.

New record. CALIFORNIA Long Beach, Rancho Los Cerritos, 1 Nov. 1991, 5o (M. J. Martinez, MCZ).

\section{Neoscona moreli (Vinson)}

Figures 18-21; Map 1

Epeira morelii Vinson, 1863: 166, 309, pl. 4, fig. 4. Specimens from Réunion.

Araneus neotheis Petrunkevitch, 1911: 305. New name for Epeira theisi: - Keyserling, which was thought misidentified. First synonymized by Grasshoff, 1986.

Neoscona neotheis: - Berman and Levi, 1971: 490, figs. 91-100, ९, ơ.

Neoscona moreli: - Grasshoff, 1986: 561, figs. 71-78, ९, ơ.

Diagnosis. The abdomen is slender and usually has a median light band with almost straight margins (Fig. 19). The conductor of the male palpus is relatively straight and the terminal apophysis has a concave edge (Fig. 20). The second tibia of the male has a dense field of short setae (Fig. 21).

Note. Figure 18 was made from a female from Depto. Valle, Colombia, Fig. 19 from Puerto Rico and Fig. 20 from a male from Depto. Meta, Colombia, Fig. 21 from a male from Cuba.

Natural History. Specimens were collected in Puerto Rican mountains, in an open abandoned parking lot, in high grasses and herbacious vegetation, and in a soybean field in Palmira, Valle, Colombia.

Distribution. Widespread in Subsaharan Africa, Madagascar, Réunion, Mauritius and Seychelles, West Indies, and with scattered records in South America (Map). I assume the species is an introduction to the Americas, judging by the limited American, and widespread African distribution.

New records. CUBA Santiago de Cuba: La Gran Piedra (MCZ). DOMINICAN REPUBLIC Monte Cristi: ca. desemboca Jura del Río Yaque del Norte (F. Alayón, MNHNC). BAHAMA ISLANDS South Caicos (AMNH). VIRGIN ISLANDS St. Croix (AMNH, ZMK), St. Johns (AMNH), Tortola (AMNH), Little Camonoe (AMNH). NEVIS Charlestown (AMNH). MARTINIQUE Fort de 
France (MCZ). GRENADA (AMNH). VENEZUELA Bolívar: Maripa, Río Cauca (MCZ). GUYANA Rupununi: Mountain Points, $30 \mathrm{~km}$ from Dadanawa (G. F. Mees, CD). COLOMBIA Meta: Carimagua, (Eberhard 607, MCZ); 15 km SW Puerto Lopez (Eberhard 1573, MCZ); Hacienda Mozambique, $15 \mathrm{~km}$ SW Puerto Lopez (W. Eberhard, MCZ); 20 km N Río Muco, 20 km S El Porvenir (W. Eberhard, MCZ). Valle: Lago Calima (W. Eberhard, MCZ); Jamundi, Finca Ceibalito (H. Bastidas, MCZ); Palmira (MCZ). PERU Loreto: Barranca (CAS). Tacna: S Camiara (AMNH). BRAZIL Terr. Amapá: Macapá (J. Becker, MEG) in nest of Eumenes canaliculatus. Bahia: Itamaraju (MNRJ). Minas Gerais: Viçosa (MNRJ). Mato Grosso: Chapada dos Guimarães (M. Alvarenga, AMNH). Rio de Janeiro: Cidade (AMNH, MCZ). São Paulo: Guarujá (AMNH). Rio Grande do Sul: Capão da Canoa (MCN); Itapuã, Porto Alegre (MCN); Pelotas (AMNH); Santa Maria $(\mathrm{MCN})$; Torres $(\mathrm{MCN})$; Viamão, $(\mathrm{MCN})$; Xangrilá $(\mathrm{MCN})$. PARAGUAY Concepción: Fonciere, imm. (E. Reimoser, MCZ). ARGENTINA Chaco: Basail (M. Biraben, MACN). Corrientes: Solari (M. Biraben, MLP).

\section{Neoscona oaxacensis (Keyserling)}

Figures. 22-25; Map 1

Epeira oaxacensis Keyserling, 1863: 121, pl. 5, figs. 15, 16, ९. Female holotype from Oaxaca, Mexico in BMNH, examined.

Epeira cooksonii Butler, 1877: 76, pl. 13, fig. 2, ९. Six female syntypes from Albemarle Island, Galapagos, in BMNH, examined. Synonymized by Berman and Levi, 1971.

Epeira adiantoides Taczanowski, 1878: 148, pl. 1, fig. 4, ९.

Female syntypes from Chorillos [now suburb of Lima], Peru in

PAN, examined. Synonymized by Berman and Levi 1971.

Neoscona oaxacensis: - Berman and Levi, 1971: 486, figs. 78-90, ᄋ, ơ.

Diagnosis. the median light band of the abdomen has lobed margins (Fig. 23), and the palpus an S-shaped conductor (Fig. 24). The second tibia of the male has a field of short setae (Fig. 25).

Variation. Specimens from the Galapagos Islands are among the largest ones in collections and females have a slightly shorter epigynum. Males have the edge of the terminal apophysis concave, 
more like that of $N$. moreli (Fig. 20). Smaller males have fewer leg setae than large specimens.

Note. Figure 22 was made from a female from Yucatan, Mexico, Figure 23 from Galapagos and Figure 24 from California, Figure 25 from a large male from Galapagos.

Natural History. Collections came from a Honduran sorghum field, buildings and herbs from northern Colombia, and from vegetation in salty ditch with Australian pine (Casuarina), S of Lima, Peru.

Distribution. Kansas and California south to Venezuela and Peru. Very common in California and Mexico.

New records. WEST INDIES Curaçao: Willemstad (AMNH). HONDURAS $37 \mathrm{~km}$ E Tegucigalpa (AD). NICARAGUA Isla de Ometepe (JMM); Léon (JMM); Volcán Mombacho (JMM). COSTA RICA San José: San José (AMNH). Guanacaste: Palo Verde (AMNH, MCZ), Cañas (MCZ). VENEZUELA Sucre: Cumaná (MCN). COLOMBIA Magdalena: Gaira (MCZ), Punta de Betin, Santa Marta (SMF). Atlantico: Barranquilla (JAK). César: Valledupar (AMNH). Antioquia: Mutatá (MCZ). Valle: Lago Calima (MCZ). ECUADOR Galapagos Isl., common (MCZ). Manabi: Bahía de Caráquez (AMNH). PERU ?Tumbes: Negritas [?Negrita] (CAS). Lima: $40 \mathrm{~km} \mathrm{~S} \mathrm{Lima} \mathrm{(MCZ).}$

Overlooked species and synonymies

Alpaida O. P.-Cambridge

Alpaida O. P.-Cambridge, 1889: 52. Type species by monotypy $A$. conica.

Pickardiana Mello-Leitão, 1943: 192. Type species by monotypy Epeira truncata Keyserling, 1865 (= Alpaida truncata). NEW SYNONYMY.

Alpaida tullgreni (Caporiacco)

Figures 26, 27

Parawixia tullgreni Caporiacco, 1955: 348, fig. 31, ơ. Male holotype from Rancho Grande, Aragua, Venezuela, in MUCC, examined. Placed in the genus Alpaida first by Levi, 1992: 8 . 

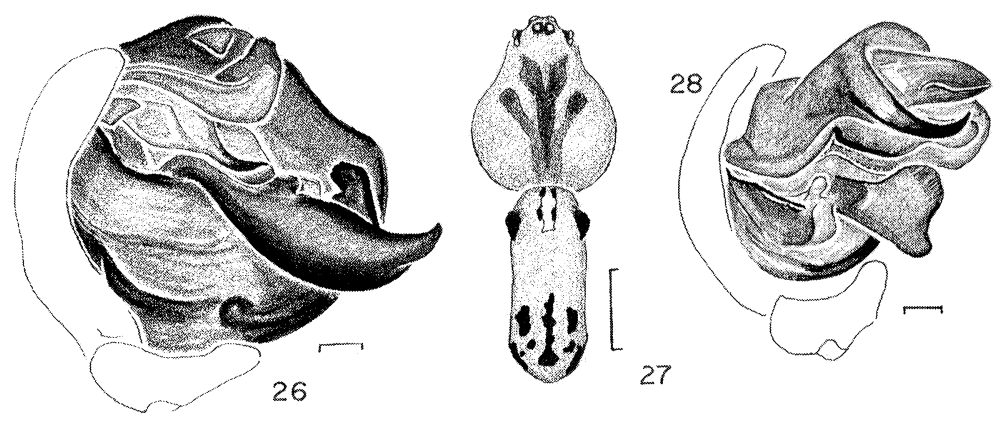

Figures 26, 27. Alpaida tullgreni, male. 26, left palpus. 27, dorsal. Figure 28. Aculepeira aculifera, male palpus.

Scale lines $12 \mathrm{~mm}$; genitalia $0.1 \mathrm{~mm}$.

Note: This species was overlooked when I revised Alpaida and was not illustrated in the paper on the genus Parawixia (Levi, 1992).

Description. Male holotype. Carapace brown, with eyes on black spots, and with branched darker brown mark. Sternum brown with large central black spot. Legs brown. Abdomen in poor condition, with black and white patches (Fig. 27), venter black with a pair of white marks. Posterior median and lateral eyes 0.8 diameter of anterior medians. Anterior median eyes 1.3 diameters apart, 2 from laterals. Posterior median eyes slightly more than 1 diameter apart, slightly more than 2 from laterals. Ocular quadrangle as long as wide behind, wider in front. No hook on first coxa. The second tibia short and not modified. Articular membrane of first femur and patella extending on venter of femur to one quarter its length. Abdomen longer than wide with anterior humps (Fig. 27). Palpus with one patellar seta. Total length $4.0 \mathrm{~mm}$. Carapace $2.1 \mathrm{~mm}$ long, 1.7 wide. First femur $2.2 \mathrm{~mm}$, patella and tibia 2.6, metatarsus 1.4 , tarsus 0.7 . Second patella and tibia $2.0 \mathrm{~mm}$, third 1.4 , fourth 2.1 .

The illustrations were made in 1971 from the holotype.

Diagnosis. The male is probably close to Alpaida almada Levi, but differs by the branched pattern on the carapace, by the marks 
on the abdomen (Fig. 27), and the shape of the large median apophysis of the palpus (Fig. 26).

\section{Aculepeira aculifera (O. P.-Cambridge)}

Figure 28

Epeira helveola O. P.-Cambridge, 1889: 24, pl. 5, figs 1, 2, ९, ơ. Female and male syntypes from Ciudad México, Mexico in BMNH no. 1905.4.28.3164-3165, examined. NEW SYNONYMY. Epeira aculifera O. P.-Cambridge, 1889: 29, pl. 7, fig. 3, ९.

Female holotype from southern slope of Volcán de Fuego, Guatemala, in BMNH, examined. Aculepeira aculifera: - Levi 1991a: 304, figs. 566-577.

Synonymy. The male was temporarily placed in Metazygia because of the median apophysis lacking spines and flagella (Fig. 28) and the palpal patella having only one macroseta. Reexamining the specimens when revising Metazygia I noticed that the posterior median eyes face forward and to the sides as in Aculepeira species and very differently from those of Metazygia. The female is Aculepeira aculifera: the female epigynum is similar to that illustrated by figures 574 and 575 (Levi, 1991a). The male and female seem to belong together: it appears that in the male syntype one palpal patellar seta of the two is broken off and that both flagella of both left and right median apophyses are broken. The name aculifera can be kept for the species since page priority does not apply.

Description. Male syntype of Epeira helveola. Color as in female. Dorsum of abdomen with similar folium, venter with a pair of white spots near spinnerets. Posterior median eyes same diameter as anterior medians, laterals 0.8 diameter. Anterior median eyes 1.1 diameters apart. Posterior median eyes 1.1 diameters apart. Ocular quadrangle slightly narrower behind than in front. Height of clypeus equals one diameter of anterior median eye. Endite with tooth, palpal femur with facing tubercle. Palpal patella with one macroseta (second may be broken off). First coxa with minute hook. Second tibia thicker than first. Abdomen ovoid. Total length $4.5 \mathrm{~mm}$. Carapace $2.5 \mathrm{~mm}$ long, 2.0 wide, behind lateral eyes 0.9 wide. First femur $2.9 \mathrm{~mm}$, patella and tibia 3.6, metatarsus 2.5, tarsus 0.9 . Second patella and tibia $3.0 \mathrm{~mm}$, third 1.4 , fourth 2.3 
Diagnosis. The male has a much smaller conductor (behind prong in Fig. 28) than that of A. packardi (Thorell) (Levi, 1977, figs. 159-160) and differently shaped median apophysis with a lobe below the "fish-tail" (Fig. 28) than that of A. packardi or A. callaria (Levi 1991a, fig. 565).

\section{CORRECTIONS}

The revision of the Neotropical Araneus (Levi, 1991a) unfortunately had several misprints. Most important is a misprint of the key on p. 186.

67(66) Epigynum with large round bordered opening in ventral or posterior view (figs. 100, 102, 113) 68

Epigynum otherwise $.70($ not 69$)$ 68(67) Openings ventral on each side of scape (fig. 113)

$69($ not 70$)$

Openings posterior on each side (figs. 100, 102); Amazon (map 2) horizonte 69(68) Openings touching scape (fig. 113); median plate narrowing ventrally in posterior view (fig. 114); Venezuela, Brazil (map 2) bandelieri

Openings not touching scape (fig. 168); median plate wide in posterior view (fig. 169); Peru to northern Chile.

koepckeorum

70(67) Length of scape about twice that of base (figs. 272, 276, 279) .71

On p. 204 and 302 (Levi, 1991a) the word Records, rather than the word Paratype, should be the indented heading, the same also in Levi (1991b) p. 402, line 1.

On p. 298 (Levi, 1991a), second column, couplet 4(3), read vittata not lisei.

The holotype of Aculepeira machu (p. 302) is now in the MUSM, not USNM; the same for the holotype of Wagneriana silvae (Levi, 1991b, p. 409).

\section{Larinia Simon}

Harrod, Levi and Leibensperger, 1991, was actually published in February 1991, not 1990. Drexelia scriba Mello-Leitão, 1940 
from Colatina, Espirito Santo, Brazil in MNRJ is not lost; it was examined and illustrated earlier as Alpaida scriba (Mello-Leitão).

\section{SUMMARY}

Neoscona marcanoi $\mathrm{n}$. sp. is described from Hispaniola. There are new illustrations for the 4 Neotropical species and a new key and records for the South American species of Neoscona. Alpaida tullgreni from Venezuela and the male Aculepeira aculifera are illustrated. There is a correction for the key to Neotropical Araneus species.

\section{REFERENCES Cited}

Berman, J. AND H. W. Levi

1971. The orb weaver genus Neoscona in North America (Araneae: Araneidae). Bull. Mus. Comp. Zool. 141(8): 465-500.

BUTLER, A. G.

1877. Myriopoda and Arachnida in Günther, Account of the zoological collections made during the visit of H. M. S. Peterel to the Galapagos Islands. Proc. Zool. Soc. London, 1877: 75-77, pl. 13.

CAmbridge, F. P.-

1904. Arachnida. Araneida. 2: 465-545. In Biologia Centrali-Americana, Zoologia, London.

Cambridge, O. P.-

1889-1902. Arachnida. Araneida. 1: 1-317. In Biologia Centrali-Americana, Zoologia, London.

CAPORIACCO, L. DI

1955. Estudios sobre los aracnidos de Venezuela. Acta Biol. Venez. 1(16): 265-448.

GRASSHOFF, M.

1986. Die Radnetzspinnen-Gattung Neoscona in Afrika (Arachnida: Araneae). Ann. Mus. Roy. de l'Afrique Centrale, Tervuren, Scienc. Zool. 250: 1-123.

HARRod, J. C., H. W. LEVI, AND L. B. LeIBENSPERger

1991. The Neotropical orb weavers of the genus Larinia (Araneae: Araneidae). Psyche, 97: 241-265.

KEYSERLING, E.

1864. Beschreibungen neuer Spinnen. Verh. zool.-bot. Ges. Wien, 1863: 63-98, 119-154, pl. 1-7.

1865. Beiträge zur Kenntniss der Orbitelae Latrl. oder Epeiridae Sund. Sitzungsber. zool.-bot. Ges. Wien, 15: 799-856.

1885. Neue Spinnen aus Amerika. Verh. zool.-bot. Ges. Wien, 34: 489-534.

KoCH, L.

1875. Aegyptische und abyssinische Arachniden, Nürnberg, 1-96, pl. 1-7. 
LEVI, H. W.

1977. The orb-weaver genera Metepeira, Kaira, and Aculepeira in America North of Mexico (Araneae: Araneidae). Bull. Mus. Comp. Zool. 148: 185-238.

1991a. The Neotropical and Mexican species of the orb-weaver genera Araneus, Dubiepeira and Aculepeira (Araneae: Araneidae). Bull. Mus. Comp. Zool. 152(4): 167-315.

1991b. The Neotropical orb-weaver genera Edricus and Wagneriana (Araneae: Araneidae). Bull. Mus. Comp. Zool. 152(6): 363-415.

1992. Spiders of the orb-weaver genus Parawixia in America (Araneae: Araneidae). Bull. Mus. Comp. Zool. 153(1): 1-46.

in press. The Neotropical orb-weaving spiders of the genera Wixia, Pozonia and Ocrepeira (Araneae: Araneidae). Bull. Mus. Comp. Zool.

LuCAS, $\mathrm{H}$.

1839. Arachnides, Myriapodes et Thysanoures. in Barker-Webb, P. and Berthelot, S. in Hist. Natur. Iles Canaries, 2(2): 19-52, pl. 6, 7.

MARTinez, M. J.

in press. A new orb-weaving spider introduction for California. Pan-Pacific Entomol.

Mello-Leitão, C. F.

1940. Aranhas do Espiríto Santo coligidas por Marío Rosa em 1936 e 1937. Arq. Zool. Est São Paulo, 2(5): 199-214.

1941. Catalogo das Aranhas do Colombia. An. Acad. Bras. Cienc. 13: 233-300.

1943. Catalogo das aranhas do Rio Grande do Sul. Arq. Mus. Nacion., Rio de Janeiro, 37: 147-245.

Petrunkevitch, A.

1911. Synonymic Index-Catalogue of Spiders. Bull. Amer. Mus. Natur. Hist.

SIMON, E. 29: 1-791.

1864. Histoire naturelle des Araignées (Aranéides). Paris, 540 pp.

TACZANOWSKI, L.

1873. Les Aranéides de la Guyane française. Horae Soc. Entom. Rossicae, 9: 64-150.

1878. Les Aranéides du Pérou central. Horae. Soc. Entomol. Rossicae, 14: $140-175$.

VINSON, A.

1863. Aranéides des îles de la Réunion, Maurice et Madagascar, Paris, 1-337, $14 \mathrm{pl}$.

WALCKENAER, C. A.

1841. Histoire naturelle des Insectes Aptères. 2: 1-549. 

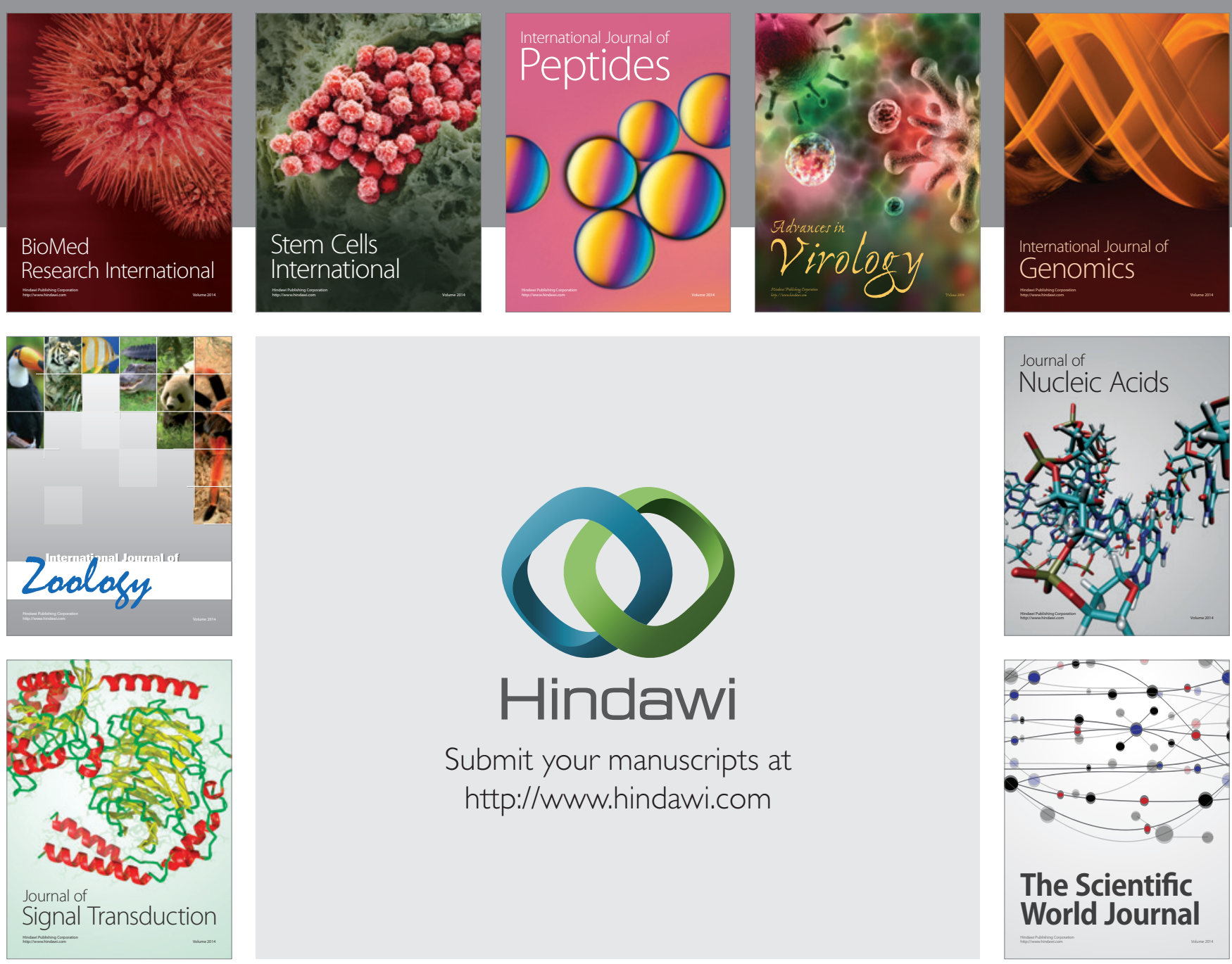

Submit your manuscripts at

http://www.hindawi.com
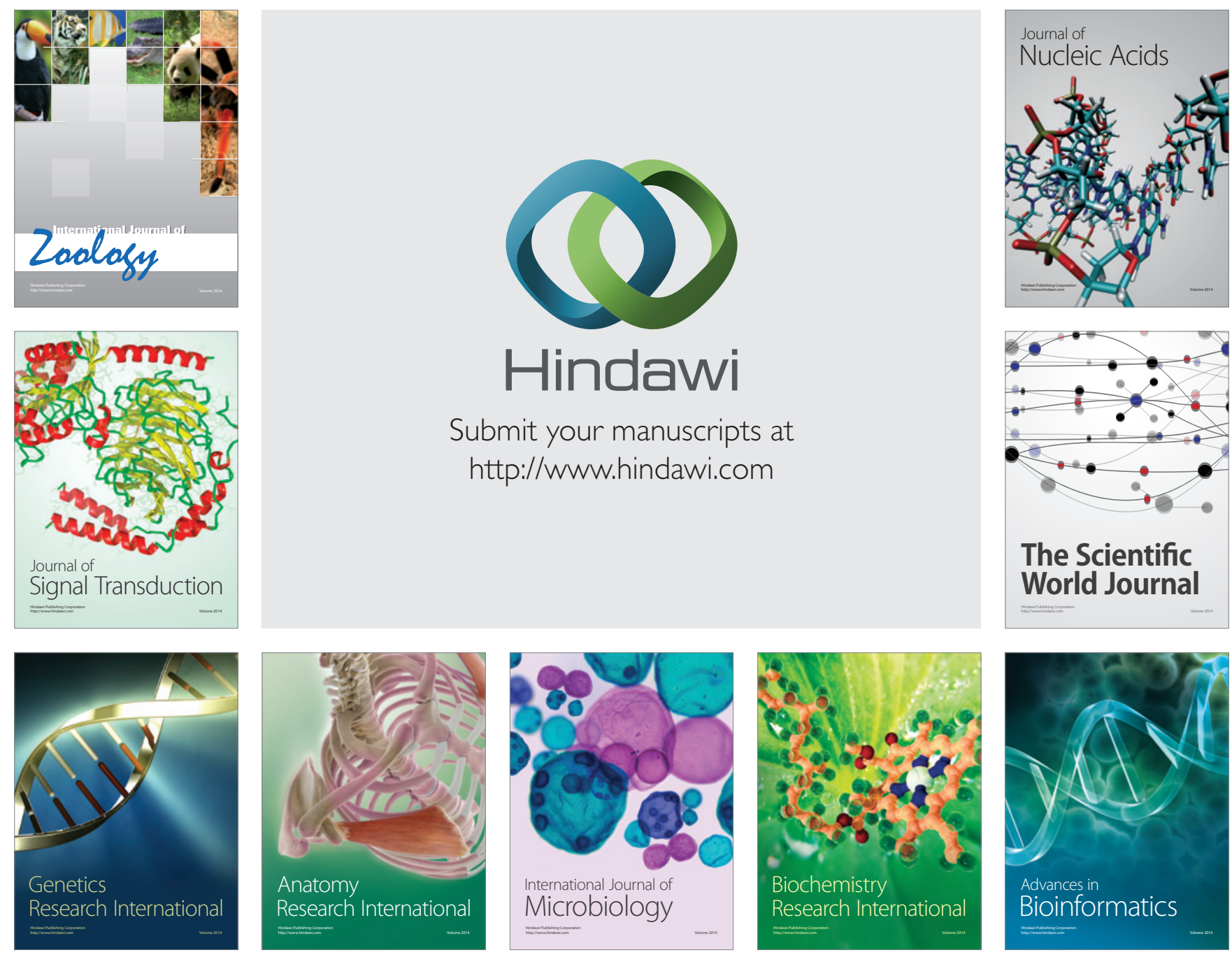

The Scientific World Journal
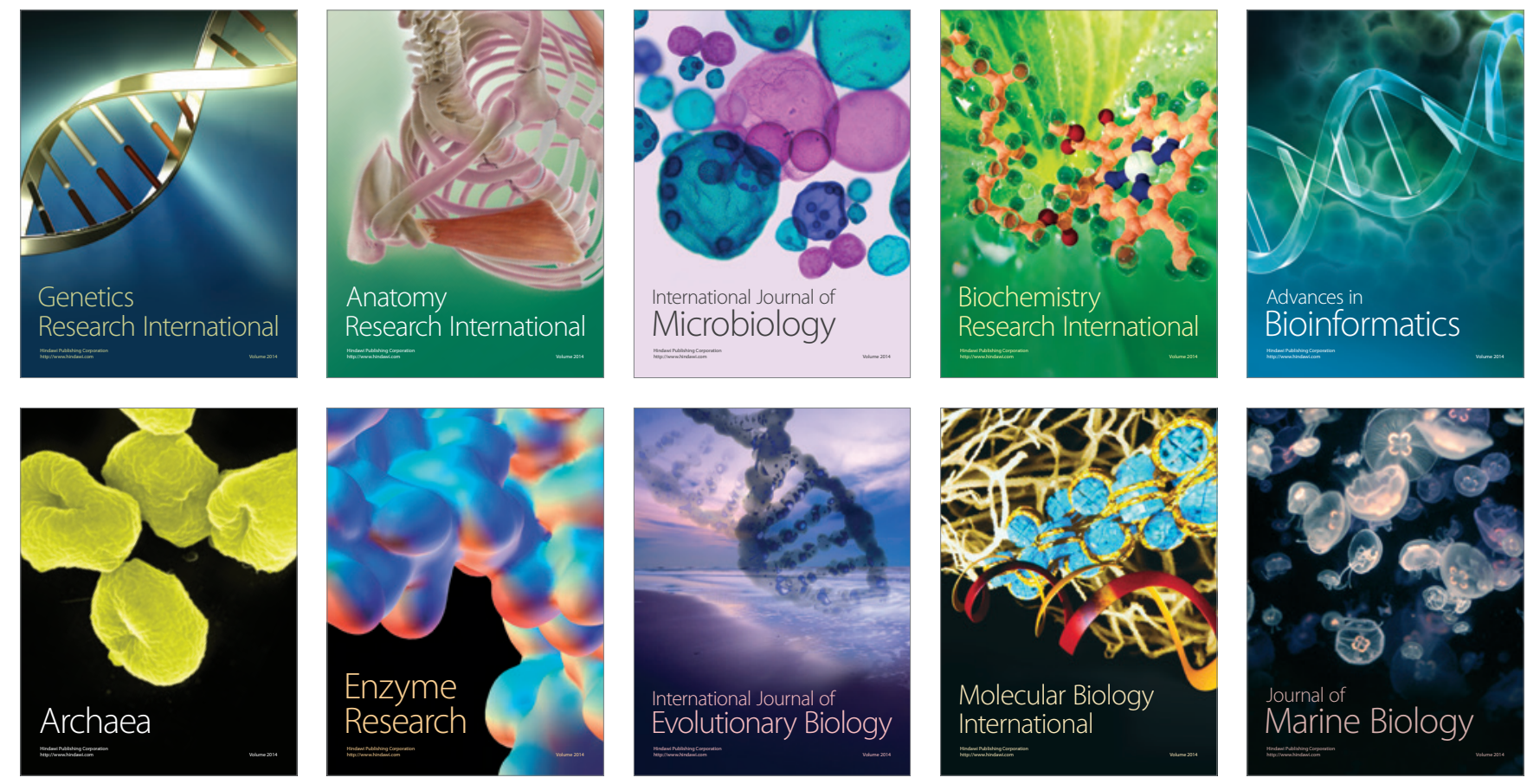